\title{
SEVERE SINUS BRADYCARDIA SECONDARY TO THE USE OF INTRAVENOUS STEROIDS.
}

\author{
Laura Linares Carsí ${ }^{1}$, María Tallón García ${ }^{1}$, Ana María Ocampo Alvarez ${ }^{1}$, Raquel Cantero \\ Rey $^{1}$, Cristina Lorenzo Fírvida ${ }^{1}$, and Inmaculada Fernández Santamarina ${ }^{1}$
}

\section{${ }^{1}$ Alvaro Cunqueiro Hospital}

November 23, 2020

\begin{abstract}
High-dose glucocorticoids are commonly used for a wide variety of childhood diseases. They are known to cause several sideeffects by oral administration; nonetheless, side-effects associated with intravenous bolus are not well known1. Whereas a rise in blood pressure is a well-known side-effect of corticosteroid treatment, sinus bradycardia has been reported as another adverse effect of high-dose glucocorticoid therapy2. This effect mainly occurs in adults and few cases have been described in children. We report two cases of sinus bradycardia due to intravenous methylprednisolone administration in paediatric oncology patients and the approach we adopted for their resolution.
\end{abstract}

\section{Hosted file}

title page.pdf available at https://authorea.com/users/377901/articles/494537-severe-sinusbradycardia-secondary-to-the-use-of-intravenous-steroids

\section{Hosted file}

SEVERE SINUS BRADYCARDIA SECONDARY TO THE USE OF INTRAVENOUS STEROIDS.pdf available at https://authorea. com/users/377901/articles/494537-severe-sinus-bradycardia-secondary-tothe-use-of-intravenous-steroids 